\title{
CHALLENGES AND PROSPECTS OF ENTREPRENEURSHIP DEVELOPMENT AND JOB CREATION FOR YOUTH: A CASE STUDY OF BIRGUNJ, NEPAL
}

\author{
Shiva Raj Ghimire* \\ Dipendra Kumar Chaudhary, PhD**
}

\begin{abstract}
This research paper is focused on youth employment and entrepreneurship development in Nepal. The objectives of this research paper are to investigate the obstacles that young people encounter when setting-up their businesses and to assess the issues related to youth unemployment in Birgunj, Nepal. This study adopted a descriptive research design and quantitative research methodology. 62 sample sizes was randomly selected from a population of 124 young entrepreneurs from different Small and Medium Enterprises (SMEs) and industries, who formally registered their businesses on Birgunj Chamber of Commerce and Industries (BiCCI) at Birgunj, which promotes and develop entrepreneurship among youth in Birgunj.

The findings were illustrated in tables, bars and pie charts, and the objectives of this study were met. The conclusion of this study revealed that most important obstacles that young entrepreneurs of Birgunj encounter while setting up their businesses, and subsequently operating their businesses include; financial constraint is the most critical bottleneck to start up a new business, lack of support structures, ineffective programs of Nepal government to support entrepreneurial development in Birgunj, high cost involvement and unclear business registration process, lack of business management skills, lack of business resources. The young entrepreneur is suffering from unfair competition. However, involvement of youth in entrepreneurial activities is also encouraging.
\end{abstract}

Keywords: Youth, Entrepreneurship, Obstacles, Challenges, Prospects, Youth entrepreneurship Development.

\section{Background}

The census finding shows that youth unemployment rate is 38 percent, which is high and the time related underemployment rate is around 8 percent. In Nepal a youth is described as any young person between the ages of 16-40. While as per Global Entrepreneurship Monitor (GEM) report, the youth refers to young people between the ages of 18-34 years and the adults refers to the people between the ages of 35-64 years. Thus, in the context of this study, youth are known as young people. Youth in Nepal constitute the mainstream of the population, comprising about 41

${ }^{*}$ Assistant Professor of Saraswati Multiple Campus (Management Faculty), Tribhuvan University, Nepal

** Assistant Professor of Birgunj College (Management Faculty), Tribhuvan University, Nepal 
percent. In recent times, youth has gradually been recognized as priority in the youth empowerment field, especially youth employment. Therefore, youth has now emerged as a separate area of attention and concern in Nepal (Peter De Schepper 2016). Nevertheless, according to the Ministry of Youth and Sports, about 38 percent of the youth population is currently unemployed and around 75 percent of them are underemployed (CBS 2016). In Nepal, lack of government policy to promote young as a business entrepreneur, it is hard for them to shows their potential in business.

The European Commission argues that academics, practitioners and policy makers worldwide have heightened their commitment towards promoting an entrepreneurial mindset within society (Commission 2013). Evidence shows that when jobs are less, especially youth are generallymore likely to be unemployed. Economic crisis crippling the job market, young people are first to be laid off. This has led to thousands of laid off workers returning to rural areas where the chances for getting alternative work are dire. Compared to adults, the youth of today are almost three times as likely to be unemployed and globally one in five working youth continue to live in extreme poverty on 1 US\$ per day (ILO October 2013). With the formal sector as many countries experiencing extremely slow growth, it is unlikely that this sector will be able to offer work opportunities to the increasing number of young people looking of jobs. GEM 2012 claims that each year 121 million young people turn 16 years old, of which $89 \%$ will potentially be searching for work in developing regions (Kelley, Singer et al. 2012). These statistics clearly state that entrepreneurship and job creation could only be viable option in present world to address future job scarcity. Therefore, young people can be created new ideas in the business environment and promoting job creation.

The focus of this research paper is to identify the current challenges faced by young entrepreneurs in Nepal. Youth entrepreneurship, therefore, has received the considerable focus after the government introduce youth self-employment program in Nepal (CBS 2016). A number of policies and agencies aimed to develop entrepreneurship through the Small and Micro Enterprise (SME) sector are introduced in Nepal, and the youth also benefited in such intervention. Universities, Colleges and some vocational training institutes introduce entrepreneurship course in their curriculum to foster and celebrate successes achieved by youth entrepreneurs. However, youth entrepreneurs have been facing an unacceptable and disappointing small and micro enterprises high failure rate, which normally occurs during their early years of operation.

\section{Objectives of the Study}

The objective of the study is to assess the entrepreneurship development and issue related to youth unemployment in Birgunj, Nepal. The specific objectives are:

- To investigate specific factors that discourages youth entrepreneurship in Birgunj.

- The study is highlighting major the issues and challenges of young entrepreneurs in Birgunj, Nepal.

- To analyze the possibilities of youth entrepreneurship development in Birgunj, Nepal. 


\section{Literature Review; Unemployment}

Unemployment is the failure to obtain employment that earns wages or salaries while a person is actively seeking a job in the labor market. "It is one of the macro-economic problems which every responsible government is expected to monitor and regulate. The higher the unemployment rate in an economy the higher would be the poverty level and associated welfare deterioration."(Oladele et al, 2001, P.251-252).

A person is employed if he or she spent some of the previous week working at a paid job. A person is unemployed if he or she is not employed and has been looking for a job or is on temporary layoff. A person who fits into neither of the first two categories, such as a full-time student or retiree, is not in the labor force (Mankiw, 2001, P.34). Unemployment refers to a situation where people who are willing and capable of working but are unable to find suitable paid employment (Fajana, as cited in Oladele et al, 2011, P.251). Maric, Jeraj and Pavlin (2010) explained that the unemployed are defined as all persons above a specified age who during the reference period are "without work", but are "currently available for work" and are "seeking work", i.e. had taken specific steps in a specified reference period to seek paid employment or self-employment. Riley et al. (2010) also defined unemployment as "people able, available and willing to find work and actively seeking work but not employed.

\section{Types of Unemployment}

On the basis of causes or sources of the unemployment can be divided into different categories. Mostly unemployment is categorized into five (Riley et al. 2010; Mankiw, 2001; Federal Reserve Bank of Atlanta, 2009).

1. Seasonal Unemployment: Seasonal unemployment is the type of unemployment that arises from a decline in the economic activity in some seasons (particular time in a year) and in some sectors.

2. Frictional Unemployment: Frictional unemployment is a type of unemployment usually caused by constant changes in the labour market. It occurs due to two reasons. The first reason is when employers are not aware of the available workers and their job qualifications. The second reason is when workers are not fully aware of the jobs being offered.

3. Structural Unemployment: Structural unemployment occurs due to the structural changes in the economy. These changes eliminate some jobs while they create some new jobs for people with new skill level. The skill sets take time to develop and hence some people lose their job simply because they do not have the new required skill(s). This problem arises from mismatch between the types of jobs that are available and type of job seekers. Such mismatch may be related to skill, education level, geographical area, age, etc.

4. Cyclical (Keynesian) Unemployment: Cyclical unemployment (also known as demand deficient unemployment) occurs due to general downturn in the business activities including production and demand for the products and services. During recessional 
business conditions, only few goods are produced and for such low production, only few employment opportunities would be available.

5. Real Wage Unemployment: It is created when real wages are maintained above their market clearing level leading to an excess supply of labour at the prevailing wage rate.

\section{Entrepreneurship}

Entrepreneurship is planning, organizing and operating the enterprise assuming the risks and uncertainties. Entrepreneurship is an important process by which new knowledge is converted into products and services (Shane and Venkataraman 2000).

Entrepreneurship is the process where an entrepreneur's forms a venture by seeing the opportunity in the market, undertake the risk by the help of effective innovative idea or process and collect profit from the business. Numerous researchers in the field of entrepreneurship have not come up with single and unanimously acceptable definition for entrepreneurship (Gwija 2014).

Entrepreneurship is a process of creating or seizing and pursuing an opportunity, irrespective of the available controlled resources (Nieman 2018).

Entrepreneurship has played an important role in economic growth, innovation, and competitiveness and it may also play a role over time in poverty alleviation (Landes 1917).

\section{Entrepreneur}

The entrepreneur is the individual who lies at the heart of the entrepreneurial process, that is, the manager who drives the whole process forward(Wickham 2006). It is not always meant a single person, who tries to change the process or product through innovative manner but it is also a group of people as a single unit "team" or "entrepreneurial team". Entrepreneurs can be defines as a person who,sees the opportunities in the market, gather the required resources, create and expand the venture tomitigate the society's problem(Shane and Venkataraman 2000).

\section{Youth Entrepreneurship}

The importance of youth entrepreneurship has gained in recent years in many countries as a way of fostering employment opportunities, boosting economic competitiveness and promoting regional development. There are two roles of young entrepreneurship that draw growing attention in every country. The first is the increased number of unemployed young people compared to the rest of the population; the second is the need for greater competitiveness and the accompanying pressures for skills development and entrepreneurship as a way of addressing the pressure of globalization and liberalization (Dash and Kaur 2012). 
Although the literature on youth entrepreneurship is very limited, there is an evidence that young people think that working for themselves as a career option as it offers them an interesting job, freedom and autonomy, which other working atmosphere might not provide (Greene and Storey 2005).

Youth entrepreneurship that it is the process whereby individuals become aware of business ownership as an option or viable alternative, develop ideas for business, learn the process of becoming an entrepreneur and undertake the initiation and development of business. Youth entrepreneurship is the practical application of enterprising qualities, such as initiative, innovation, creativity, and risk-taking into the work environment (either in self-employment or employment in small start-up firms) using the appropriate skills necessary for success in that environment and culture" (Chigunta 2002).

\section{Factors Affecting Entrepreneurship}

These factors can be outlined as follows:

Education: A person who, receive entrepreneurship education and training from the environment $\mathrm{s} /$ he is brought up, therefore, play a vital role in influencing his attitude towards setting up entrepreneurial ventures (Pillania, Lall et al. 2009).

Family Role: Those people who reside within entrepreneurially oriented environment, more likely to take part in entrepreneurial activities in their career. Role model plays an importance role because they function as carriers of value, emotions and experiences towards self-employment. The study reveals that the children of self-employed parents are more likely to continue in entrepreneurial career than those who does not have their parents in self-employment. Thus, those young people whose, parents own their own business ventures may influence entrepreneurial attitudes for young people who live together in the same environment (Nieman and Nieuwenhuizen 2009).

Financial Condition: The financial conditions of a person, whether favorable or adverse, can pull or push them to start-up a new entrepreneurial venture for a variety of reason (Pillania, Lall et al. 2009).

Need for Achievement: McClelland (1961) argued that it is likely that people high in need for achievement will be more likely to pursue entrepreneurial jobs than other types of roles. High need for achievement is one of the important motivational factors, which can motivate an entrepreneur to start-up and advance in his entrepreneurial venture. This need for achievement leads an entrepreneur to accomplish his personal goals, teach how to use the available resources optimally and explore the creativity and innovativeness to produce better products and services for the market. (Pillania, Lall et al. 2009).

Focus of Control: Another motivational trait that has received attention is locus of control. Individuals who have an external locus of control believe that the outcome of an extent is out of their control, whereas individuals with an internal locus of control believe that their personal actions directly affect the outcome of an event (Rotter 1966). He further argued that individuals with an internal locus of control would be likely to seek entrepreneurial roles because they desire position in which their actions have direct impact on results (Scheiner 2009). 
Need for Independence: Independence entails taking the responsibility to use one's own judgment than blindly following the assertions of others (Shane, Locke et al. 2003). There is some existing empirical evidence which suggests that entrepreneurs may be higher in independence than other individuals(Shane, Locke et al. 2003).

Risk Taking: Risk taking is another crucial factor for the emergence of entrepreneurship, which emerged from McClelland (1965) research on entrepreneurship, individuals with high achievement needs would have moderate propensities to take risk. Entrepreneurs always take risk with respect to financial well-being, psychic well-being, career security and family relation (Shane, Locke et al. 2003).

Government Policies: Government is formulating entrepreneurship development programs and policies that promote entrepreneurial ventures in different sectors.

Business Environment: A supportive business environment that emergence of entrepreneurship is likely to occur.

Availability of financial assistance: It is crucial to have start-up capital, additional working capital or access to it, to expand and remain competitive, especially for the emergence of entrepreneurship development (Bushell 2008).

Recognition: Recognition is one of the crucial factors that may encourage an individual to startup and successfully manage his or her business venture with an expectation to gain social standing in the society (Nieman and Nieuwenhuizen 2009).

Social status: An entrepreneur social status and life style may change, if his or her venture becomes successful and lucrative, and other people who live within the community begin to regard him/her as a role model.

\section{Methodology}

Quantitative research methodology adapted for this study and applies accordingly. This study quantifies factors identified as contributing to the challenges and prospects of youth entrepreneurship development in Birgunj. Quantitative data can be transposed into numbers, in a formal, objective, systematic process to obtain information and describe variables and their relationship (Burns and Grove 1993, Wood and Brink 1998).

Exploratory and descriptive research designed is used. Exploratory in the sense that it seeks to aim and investigate unfolded area of how young entrepreneurs develop opportunities for entrepreneurship in Birgunj. This is done through the collection of available quantitative data in Nepalese context. Similarly, the analysis and discussion is descriptive in the sense that it describes the general situation of youth entrepreneurship on the basis of available primary and secondary data.

The research population for this research paper is youth entrepreneurs, who operating business in Birgunj as a member of Birgunj Chambers of Commerce \& Industries (BiCCI) and Nepalese Young Entrepreneur Forum (NYEF). 
The population for this study consists of 124young entrepreneurs whereas 62 consider as a sample.

Selection of the population for this study was based on the belief that these subjects would bring significance information on the subject matter. The reason for choosing this population includes; these entrepreneurs come from variety of section of the society, they are registered with BiCCI, which also promote and develop entrepreneurship among young people in this area

\section{Data Collection}

Questionnaires are used to collect primary data whereas journals, websites are referred to collect secondary data. The questions were constructed in such a way to answer the research question and the questions were also constructed in an attempt to obtain honest answers and details from respondents.

Total 62 questionnaires were distributed to the participants of the study but only 58 questionnaires were returned.

\section{Data Analysis}

Under this study, the presentation of the result is mainly based on the primary data collected from the questionnaires, observations, and informal discussions with young entrepreneurs in order to meet the objective of this research. The presentation and analysis of primary data collected through the questionnaire are explained below.

\section{Descriptive Analysis}

\section{(a) Demographic Profile of Respondents}

This section deals with the demographic analysis and interpretation of primary data collected through questionnaires distributed to different. This helps to get insight in to the demographic characteristics of the respondents under study.

\section{Gender of Respondents}

The summary of gender of the respondents in the survey is given in the following table.

Table-1; Gender of Respondent

\begin{tabular}{|l|r|r|}
\hline Gender Group & Frequency & Percentage \\
\hline Male & 32 & 55 \\
\hline Female & 26 & 45 \\
\hline Total & $\mathbf{5 8}$ & $\mathbf{1 0 0}$ \\
\hline
\end{tabular}

Source: Questionnaire Survey 2018 
The above table shows the gender of respondent for this survey. The figure clearly shows that $55 \%$ of respondent is male and remaining $45 \%$ is female. Majority of respondent is male. There is no doubt that, the participation of male respondent is more than female respondent.

\section{Age Group of Respondent}

The summary of age of the respondents in the survey is given in the following table.

Table 2: Age Group of Respondent

\begin{tabular}{|l|r|r|}
\hline Age Group & Frequency & Percentage \\
\hline $16-24$ & 8 & 14 \\
\hline $25-32$ & 28 & 48 \\
\hline $33-40$ & 22 & 38 \\
\hline Total & $\mathbf{5 8}$ & $\mathbf{1 0 0}$ \\
\hline
\end{tabular}

Source: Questionnaire Survey 2018

The above table shows the age of the respondent. The study included the young entrepreneurs from $16-40$ age group. From the figure it is clearly seen that, $14 \%$ of the respondent is $16-24$ age group, $48 \%$ belongs to $25-32$ age group, and 38\% are part of 33-40 age group. Majority of young entrepreneurs of Birgunjare from 25-32 age groups and the least participation is from below 24 and above 16 age group.

\section{Qualification of Respondent}

The summary of qualification of the respondents in the survey is given in the following table.

Table 3: Qualification of Respondent

\begin{tabular}{|l|c|c|}
\hline \multicolumn{1}{|c|}{ Qualification } & Frequency & Percent (\%) \\
\hline Master & 7 & 12 \\
\hline Bachelor & 18 & 31 \\
\hline Intermediate & 22 & 38 \\
\hline S.L.C. & 6 & 10 \\
\hline Literate & 5 & 9 \\
\hline Total & $\mathbf{5 8}$ & $\mathbf{1 0 0}$ \\
\hline
\end{tabular}

Source: Questionnaire Survey 2018

The above table presents the qualification of respondent in the survey. The study has includes all kinds of young entrepreneurs of Birgunj. From the figure, The small number of respondents comprising $9 \%$ of respondent had managed just to be literate, $10 \%$ of respondents have education till SLC, $38 \%$ of respondent have education up to intermediate, $31 \%$ holds bachelor degree and $7 \%$ have master and above. The majority of respondents have higher education. This highlights the need for education for those youth who start their career in entrepreneurial ventures. 


\section{Duration of Operating Business}

The duration of operating business of the respondents in the survey is given in the following table-

Table 4: Duration of Operating Business

\begin{tabular}{|l|r|r|}
\hline Duration & \multicolumn{1}{|l|}{ Frequency } & \multicolumn{1}{|l|}{ Percentage } \\
\hline Less than 1 year & 4 & 7 \\
\hline $1-3$ years & 26 & 45 \\
\hline 3-5 years & 22 & 38 \\
\hline More than 5 years & 6 & 10 \\
\hline Total & $\mathbf{5 8}$ & $\mathbf{1 0 0}$ \\
\hline
\end{tabular}

Source: Questionnaire Survey 2018

The above table indicates the duration of operating business of respondents for this study. The table clearly shows, the majority of young entrepreneurs operated their business ( $83 \%)$ between 1 5 years, followed by 10percent of young entrepreneur run business more than 5 years. Only 7 per cent of the young entrepreneurs had not completed their business even a year.

\section{Number of Employees}

The current number of employees that the respondents have in their respective business is given following table-

Table 5: Number of Employees

\begin{tabular}{|l|l|l|}
\hline No. of Employees & Frequency & Percentage \\
\hline 1 to5 & 36 & 62 \\
\hline 6 to 10 & 18 & 31 \\
\hline More than 10 & 4 & 7 \\
\hline Total & 58 & 100 \\
\hline
\end{tabular}

Source: Questionnaire Survey 2018

Table 5 shows that the majority of the respondents (62\%) have created employment for 1-5 employees in their respective business, followed by 31 percent respondent have created employment for 6-10 employees, only 7 percentage young entrepreneurs have more than 10 employees. This can conclude that majority of youth owned business is small in size.

\section{Motivation to Start Business}

The summary of motivational factors of the respondents in the survey is given in the following table. 
Table 6: Motivation to start business

\begin{tabular}{|l|r|r|}
\hline Factors & Frequency & Percentage \\
\hline Unemployment & 7 & 12 \\
\hline Business Dream & 2 & 3 \\
\hline Poverty & 4 & 7 \\
\hline Family Background & 37 & 64 \\
\hline Education \& Training & 5 & 9 \\
\hline Business Role Model & 2 & 3 \\
\hline Work Experience & 1 & 2 \\
\hline Total & 58 & 100 \\
\hline
\end{tabular}

There are various factors that inspired young people to start their own businesses. These motivational factors play most important role to be an entrepreneur. Table 6 shows that percentage (64\%) participants are continue their own family business. Due to unemployment only 12 percent participant are started their own business. Other factors does not play vital role to start business.

This study indicated that experience, knowledge, expertise and skills gained from previous work encouraged him to start their own business. Thus knowledge and experience from previous employment, as well as unsatisfactory working condition had influenced him to begin new career by establishing entrepreneurial venture.

\section{Family Business Background}

Involvement in a family business gives a good entrepreneurial exposure for young people. The following figure explains the extent to which respondent's response is given below.

Figure 1:Family Business Background

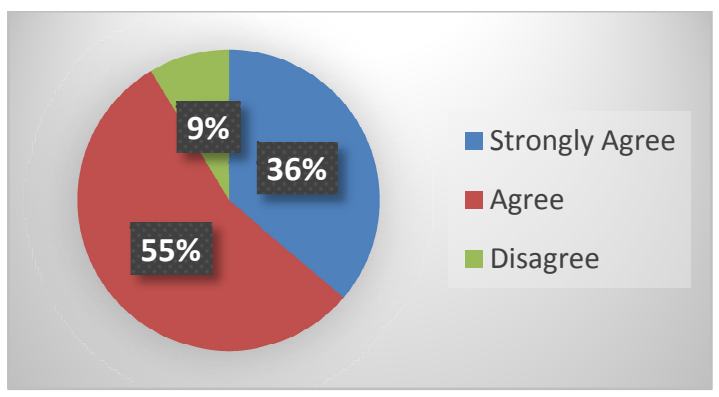

Source: Questionnaire Survey 2018

The above figure shows the involvement of family business gives the entrepreneurial foundation. The figure clearly shows, 55\% of respondents indicated that involvement in a family business would provide a good entrepreneurial exposure for the young people who are able to establish 
their own business and 36 percent of respondents also strongly support this argument. However, remaining 9 percent of respondents disagree with this statement.

\section{Entrepreneurship education and training in the business success}

Education and training can play a vital role to be a successful entrepreneur to which the participants of this study agreed or disagreed are given following figure.

Figure: 2 Entrepreneurship Educations and Training

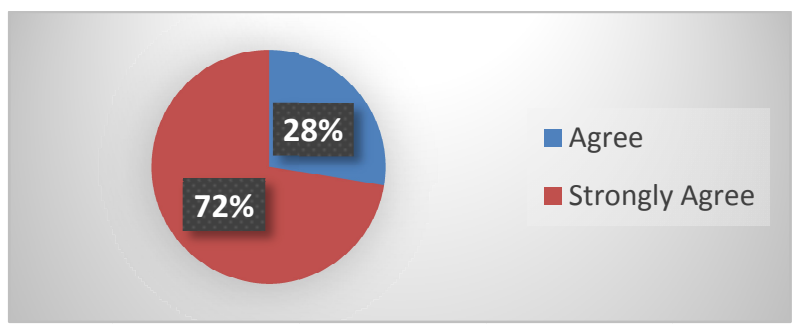

Source: Questionnaire Survey 2018

Figure 2 shows the respondents in this study (72 percent) strongly agreed that entrepreneurship education and training can play a vital role to be a successful entrepreneurs, while remaining 28 percent of respondents also agreed with the statement. Thus, the university graduates should be equipped with proper entrepreneurial skills and knowledge, which will help them to create business. Today, education has gained popularity in Nepal, even though, entrepreneurship education has not develop yet in academic sector due to lack of clear policies and strategies of government of Nepal. Private institutions and Non-governmental organizations are playing most important roles to promote entrepreneurship education in the country.

\section{Availability of Capital for Business}

The following figure indicated that facilitating the capital for business from financial institution that supports youth entrepreneurship is given below.

Figure 3: Availability of Capital for Business

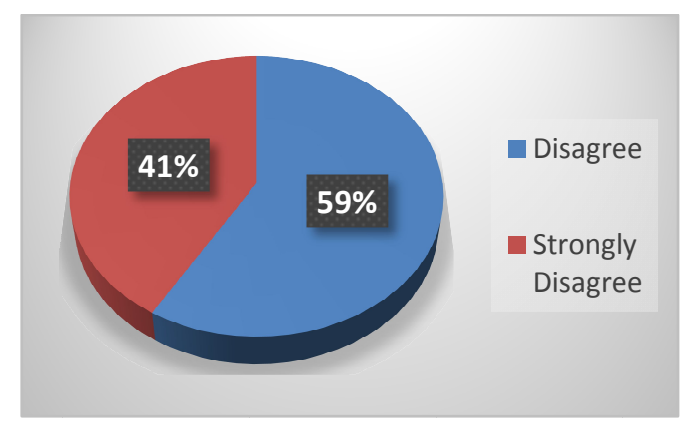

Source: Questionnaire Survey 2018 
The above figure 3 indicated that the majority of the respondents (59 percent) for this study disagreed that it is easier to access capital from financial institution that support young entrepreneurs, while remaining 41 percent respondents strongly disagreed with this statement. Availability of business capital to start business from the financial institutions is major problems for young entrepreneurs in Birgunj. Collateral is necessary to obtain loan from a bank and other lending institutions in Nepal. Lack of financial incubator, lack of business funding information center, and short of savings are major obstacles that result in their inability to get capital for business.

\section{Availability of Skills Labour}

The following figure explains the extent to which participants of this study agreed or disagreed that availability of skill labour is easier in the labor market for any kind of business.

Figure 4: Availability of Skills Labour

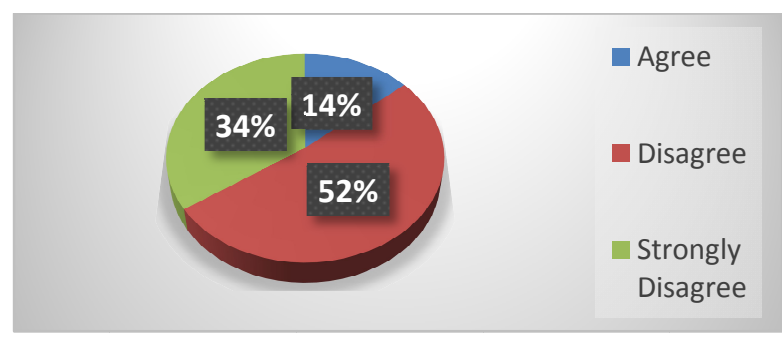

Source: Questionnaire Survey 2018

The above figure 4 indicated that almost 52 percent participants of this study disagreed that the availability of skill labour is easier to get employees in the labor market for any kind of business and 34 percent respondents strongly disagreed, while 14 percent respondents agreed with the statement.

\section{Supportive Structure for Entrepreneurship Development}

The following chart shows the extent to which the respondents of this study agreed or disagreed that young entrepreneurs in Birgunj are aware of existing supportive structures for entrepreneurship development.

\section{Figure 5: Supportive Structure for Entrepreneurship Development}

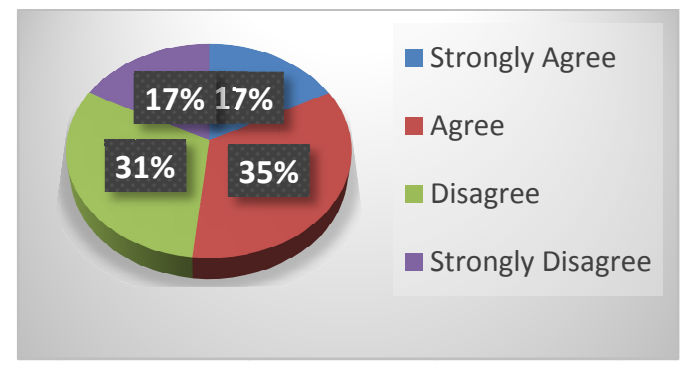

Source: Questionnaire Survey 2018 
The above figure 5 clearly presented that the 35 percent respondents of this study strongly disagree of existing supportive structure for youth entrepreneurship and 31 percent of respondents are not aware of the existing support structures. On the other hand, 17 percent respondents agreed that the existing supportive structure for entrepreneurship development and 17 percent respondents strongly agreed with this statement.

\section{Growth in Youth Entrepreneurs in Birgunj}

The following chart shows the extent to which participants of this study agreed or disagreed that the number of young entrepreneurs in Birgunj is growing.

\section{Figure 6: Growth in Youth Entrepreneurs in Birgunj}

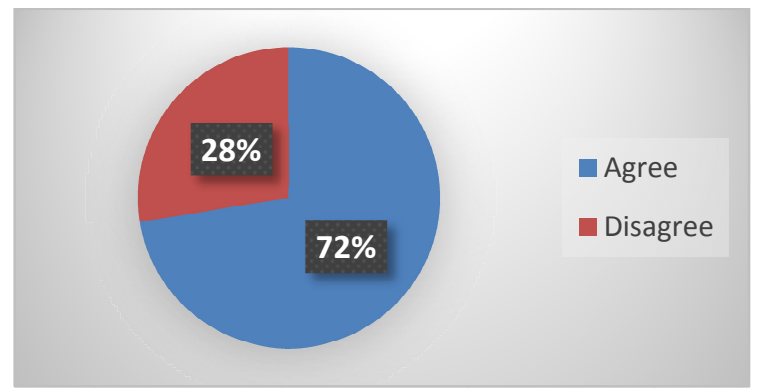

Source: Questionnaire Survey 2018

The above figure 6 indicated that 72 percent respondent agreed the number of young entrepreneurs in Birgunj is increasing, while around 28 percent participants disagreed with this statement.

\section{Supportive Government Policy and Programs for Youth Entrepreneurship}

The following chart shows the extent to which the respondents of this study agreed or disagreed that supportive government policy and programs of Nepalese government are supportive to youth entrepreneurship in Birgunj.

\section{Figure 7: Supportive Government Policy and Program}

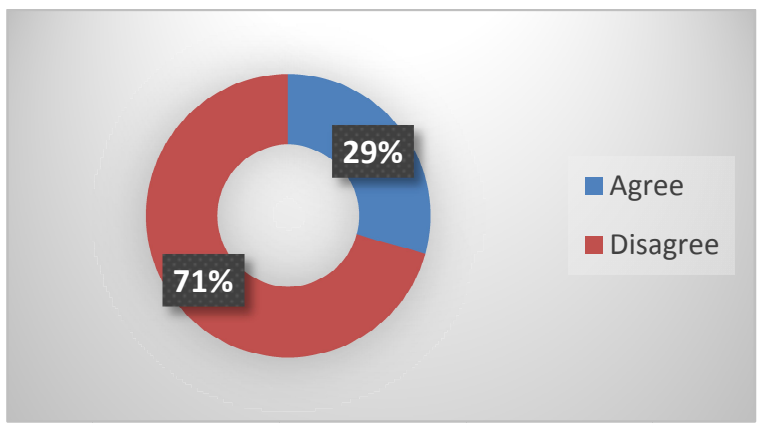

Source: Questionnaire Survey 2018 
Majority of respondents 71 percent respondents in this study disagreed with the Nepalese government policy and program are supportive to youth entrepreneurship in Birgunj, while 29 percent respondents agreed with this notion. There is no clear policy that describes the Government's intentions for the development of youth entrepreneurship. The national development plans and policies do not accord high priority for the development of youth entrepreneurship.

\section{Obstacles at Business Start-Up}

The following chart 8 shows that the extent to which the participants of this study agreed or disagreed that they faced obstacles in the course of setting up their businesses.

\section{Figure 8: Obstacles at Business Start-Up}

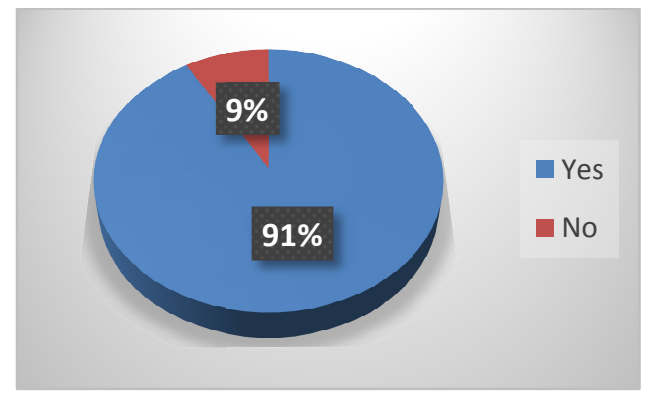

Source: Questionnaire Survey 2018

The above chart indicated that almost all of the respondents 91 percent agreed that they had certain obstacles in the course of setting up their businesses, while only 9 percent respondents disagreed with this statement. This could also be the reason about why Nepalese youth lag far behind in starting-up own business; rather choose to pursue their career as migrant workers far off in Middle East and Malaysia.

\section{Obstacle for Business Operation}

The following figure 9 indicates that the extent to which the respondents of this study agreed or disagreed that they are currently facing obstacles in the course of operating their respective business.

\section{Figure 9: Obstacle for Business Operation}

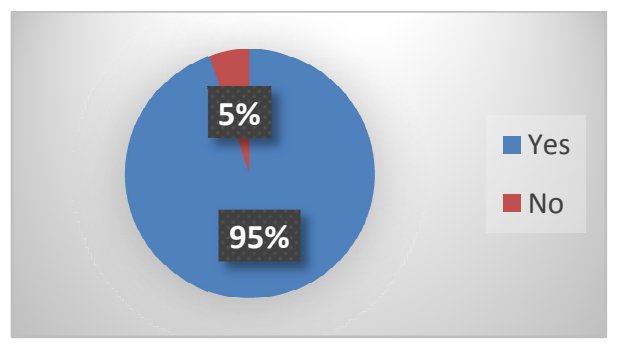

Source: Questionnaire Survey 2018 
The above chart indicated that almost all of the respondents 95 percent agreed that they had certain obstacles in the course of operating their businesses, while only 5 percent respondents disagreed with this statement.

\section{Conclusions}

The objectives of this research paper are to investigate the obstacles that young people encounter when setting-up their businesses and to assess the issues related to youth unemployment in Birgunj, Nepal. This research indicated that youth entrepreneurship development initiatives is lacking in Birgunj. Young entrepreneurs in Birgunj are devoid of business development services such as business counseling, finance, mentoring, and incubators. Lack of youth supportive government program and policy is another factor of young entrepreneur's development in this area and other agencies likes NGOs, INGOs and donor agencies are also play ineffective role to promote entrepreneurial development in Birgunj. There is no clear policy that describes the Government's intentions for the development of youth entrepreneurship. Capital collection is the key obstacle for starting their business. Financial institutions of Nepal are not playing supporting role to youth entrepreneurship development in Birgunj. Because of scarcity of funds many young entrepreneurs in Birgunj have been unable to expand their businesses. The process for registration of business for young entrepreneurs in Birgunj is not easy and quick and the process of registration is too difficult, lengthy and costly. Availability of skills manpower is also one of the major obstacles in setting-up of youth entrepreneurial ventures in Birgunj. Thus, young entrepreneurs should find the ways to overcome this challenge.

This research also found that majority of youth owned business is small in size and capital. The most important obstacles of young entrepreneurs encounter while setting up their businesses, and subsequently operating their businesses include; lack of support structures, ineffective programs of Nepalese government to support entrepreneurial development, lack of business funding and start-up capital, high cost involvement and unclear business registration process, lack of business management skills, lack of business resources and so on. Interestingly, despite having so many challenges found by this study in the course of establishing and running entrepreneurial ventures in Birgunj, some good prospect also emerged. Majority of respondents felt that the number of youth owned enterprises are growing daily. Young people are starting out new ventures in various fields, from agro-business to outsourcing. The importance of entrepreneurship is slowly being recognized. This indicates a growing interest in youth entrepreneurship, the issue of sustaining and promoting their interest should be the attention of all stakeholders. Another finding of the research is entrepreneurial and managerial skills would boost chance of success in their businesses. 


\section{References}

Burns, N. and S. Grove (1993). "The practice of nursing." WB Saunders. Philadelfia, Usa.

Bushell, B. (2008). "Women entrepreneurs in Nepal: what prevents them from leading the sector?" Gender \& Development 16(3): 549-564.

CBS (2011). National Population and Housing Census 2011. Kathmandu, Nepal, Central bureau of Statistics Nepal.

Chalise, B. (2014). "Remittance and its Effect on Entrepreneurial Activities: A Case Study from Kandebas Village Development Committee, Nepal." IZMIR REVIEW OF SOCIAL SCIENCES 2(1).

Chigunta, F. (2002). Youth entrepreneurship: Meeting the key policy challenges, Education Development Center.

Chimucheka, T. (2012). "Impediments to youth entrepreneurship in rural areas of Zimbabwe." African Journal of Business Management 6(38): 10389-10395.

Commission, E. (2003). "The Commission’s Green Paper: Entrepreneurship in Europe."

Cornell, R. (2001). Putting the Young in Business: Policy Challenges for Youth Entrepreneurship. Territorial Development. LEED Notebook No. 29, ERIC.

Creswell, J. W. (1998). Qualitative inquiry and research design: Choosing among five designs, Thousand Oaks, CA: Sage.

Dash, M. and K. Kaur (2012). "Youth entrepreneurship as a way of boosting Indian economic competitiveness: a study of Orissa." International Review of Management and Marketing 2(1): 10-21.

Granovetter, M. S. (1973). "The strength of weak ties." American journal of sociology: 13601380. 107

Greene, F. J. and D. Storey (2005). Evaluating youth entrepreneurship: the case of The Prince's Trust, Centre for Small and Medium Sized Enterprises, Warwick Business School.

Gwija, S. A. (2014). Challenges and prospects of youth entrepreneurship in Khayelitsha, Western Cape.

Gwija, S. A., C. Eresia-Eke and C. G. Iwu (2014). "Challenges and Prospects of Youth Entrepreneurship Development in a Designated Community in the Western Cape, South Africa."

ILO (october 2008). "Global Employment Trends for Youth."

Jodl, K. M., A. Michael, O. Malanchuk, J. S. Eccles and A. Sameroff (2001). "Parents' roles in shaping early adolescents' occupational aspirations." Child development: 1247-1265.

Kelley, D. J., S. Singer and M. Herrington (2012). "The global entrepreneurship monitor." 2011 Global Report, GEM 20117. 
L., M. (2001). "Enabling environment for women enterprises, "challenges and ways", Social Finance Units, International Labour Office, Geneva."

Landes, D. S. (1998). "The wealth and poverty of nations: why some countries are so rich and some so poor." New York, NY: WW Noton.

Lingelbach, D. C., L. De La Vina and P. Asel (2005). "What's distinctive about growth-oriented entrepreneurship in developing countries?" UTSA College of Business Center for Global Entrepreneurship Working Paper(1).

Mankiw, G. (2001).Macroeconomics (5th ed.).TSI graphics. Harvard University.

Maric, M., Jeraj, M., \&Pavlin, J. (2010). Entrepreneurship as a solution to the unemployment problem. University of Maribor, Faculty of Organizational Sciences. Working paper series: 005.961:005.914.3.

Matthews, C. H. and S. B. Moser (1996). "A Longitudinal Investigation of the Impact of Family Bac." Journal omeall Business Management; Apr 34: 2.

McClelland, D. C. (1965). "N achievement and entrepreneurship: A longitudinal study." Journal of personality and Social Psychology 1(4): 389.

Murithii, C. (2013). "Youth Polytechnics Education and Entrepreneurship in Kenya;(Are We Promoting Entrepreneurs?)." International Journal of Academic Research in Business and Social Sciences 3(5): 491.

Nafukho, F., M. Kobia and D. Sikalieh (2010). "Towards a search for the meaning of entrepreneurship." Journal of European industrial training 34(2): 110-127.

Nieman, G. and C. Nieuwenhuizen (2009). Entrepreneurship: A South African Perspective, Van Schaik.

Nieman, G. N., C. (2009). "Entrepreneurship. A South African Perspective. 2nd Ed. Cape Town: Interpak Books."

Ohlhoff, J. (2008). "The Relationship between Employer-Of-Choice Status And Employer Branding." Journal of business and management dynamics 8.

Oladele, P. O., Akeke, I., \&Oladunjoye, O. (2001). Entrepreneurship Development: A Panacea

for Unemployment Reduction in Nigeria. Journal of Emerging Trends in Economics

and Management Sciences (JETEMS), 2 (4), 251-256.

Peter De Schepper, B. R. P. (2010). "Generation in Dialogues, Youth in Politics: ." youth initiatives: 5 .

Pillania, R. K., M. Lall and S. Sahai (2009). "Motives for starting business: Indian women entrepreneurs perspectives." International Journal of Indian Culture and Business Management 3(1): 48-67. 
Rahmawati, F., A. Hasyyati and H. L. Yusran (2012). The obstacles to be Young Entrepreneur. Proceedings of the international conference on business and management, Phuket, Thailand.

Reynolds, P. D., W. D. Bygrave, E. Autio, P. Arenius and G. E. Monitor (2004). GEM 2003 global report, Babson College.

Riley, G., Tarrant, R., Bridges, P. and White, B. (2010). Students' Revision Workshop:

Employment and unemployment.

Robinson, P. B., D. V. Stimpson, J. C. Huefner and H. K. Hunt (1991). "An attitude approach to the prediction of entrepreneurship." Entrepreneurship theory and practice 15(4): 13-31.

Rotter, J. B. (1966). "Generalized expectancies for internal versus external control of reinforcement." Psychological monographs: General and applied 80(1): 1.

Scheiner, C. W. (2009). Fundamental determinants of entrepreneurial behaviour, Springer.

Scherer, R. F., J. S. Adams, S. Carley and F. A. Wiebe (1989). "Role model performance effects on development of entrepreneurial career preference."

Schoof, U. (2006). Stimulating Youth Entrepreneurship: Barriers and incentives to enterprise start-ups by young people, International Labour Organization.

Shane, S. and S. Venkataraman (2000). "The promise of entrepreneurship as a field of research." Academy of management review 25(1): 217-226.

Shepherd, D. A., H. Patzelt and J. M. Haynie (2010). "Entrepreneurial Spirals: Deviation-Amplifying Loops of an Entrepreneurial Mindset and Organizational Culture." Entrepreneurship theory and practice 34(1): 59-82.

Stevenson, H. H. and W. A. Sahlman (1989). "The entrepreneurial process." Small business and entrepreneurship: 94-157.

Van Auken, H., F. L. Fry and P. Stephens (2006). "The influence of role models on entrepreneurial intentions." Journal of Developmental Entrepreneurship 11(02): 157-167.

Van Rensburg, L. (2010). National Report into the state of entrepreneurship. Can entrepreneurship be taught/learned?

Wickham, P. A. (2006). Strategic entrepreneurship, Pearson Education. 